\title{
Wizerunek kobiety II połowy XIX i początku XX w. w świetle wybranych czasopism kobiecych i rodzinnych Królestwa Polskiego
}

Kobieta od zarania dziejów pełniła w rodzinie istotną funkcję, chociaż nie zawsze jej pozycja odpowiadała wykonywanym obowiązkom. Jako wychowawczyni własnych dzieci kształtowała charaktery młodego pokolenia, pośrednio oddziaływała więc na całe społeczeństwo i wyznawane przez nie wartości. Jej rola wzrosła w okresie zaborów, kiedy uczyniono ją odpowiedzialną za trwanie w narodzie ducha polskości i przekazanie dzieciom tradycji przodków. Nie każda matka potrafiła jednak sprostać stawianym jej oczekiwaniom. Dlatego też w XIX w. wykorzystano prasę do kształtowania postaw i systemu wartości kobiet - żon, matek i wychowawczyń młodego pokolenia. Czasopisma kierowane do kobiet pojawiły się już na początku XIX w. W 1820 r. ukazało się pierwsze pismo, którego tytuł wskazywał na nowy typ adresata - kobietę: „Wanda. Tygodnik Polski Płci Pięknej i Literaturze Poświęcony”. W następnych latach redagowano jeszcze sześć takich magazynów ${ }^{1}$. Dopiero jednak w stosunku do czasopism wydawanych po 1860 r. można stwierdzić, że były one „kobiece” nie tylko z nazwy. Adresowane do kobiet, rzeczywiście poruszały tematy im bliskie, a wśród redaktorów i publicystów występowały przedstawicielki płci pięknej. Istotną rolę w rozwoju prasy kobiecej odegrał nasilający się w drugiej połowie XIX w. ruch emancypacyjny. Jednocześnie przedstawiciele pozytywizmu, głosząc hasła pracy u podstaw i pracy organicznej, wykorzystywali prasę w celu kształtowania poglądów i opinii społeczeństwa². Redaktorzy i publicyści magazynów kobiecych, dostrzegając przeobrażenia społecznej i rodzinnej pozycji niewiast, poruszali zagadnienia związane z ich życiem i pracą. Lansowane poglądy dotyczące tego, kim kobieta być powinna, jakimi cechami charakteru ma się odznaczać oraz do

* Dr, Zakład Teorii Wychowania, Instytut Pedagogiki, Wydział Pedagogiki i Psychologii, Uniwersytet Marii Curie-Skłodowskiej w Lublinie, ul. Narutowicza 12, 20-004 Lublin.

1 J. F r a n k e, Polska prasa kobieca w latach 1820-1918, Warszawa 1999, s. 323-324.

2 B. Golk a, Kształtowanie się wiedzy o prasie w Polsce XIX w., Warszawa 1969, s. 122; J. Łoj e k, J. M y śli ń s k i, W. W ła d y k a, Dzieje prasy polskiej, Warszawa 1988, s. 55. 
czego w życiu dążyć niewątpliwie kształtowały oczekiwania społeczne. Często w artykułach poruszano problematykę rodzinną i wychowawczą, analizowano rolę rodziny w życiu dziecka i całego społeczeństwa.

\section{Profile czasopism kobiecych}

Czasopisma kierowane do kobiet miały różne profile, były dostosowane do zróżnicowanych potrzeb i poziomu umysłowego czytelniczek. Można wśród nich wyróżnić magazyny o profilach: rodzinnym („Kółko Domowe”, „Ognisko Domowe”, „Opiekun Domowy”, „Dobra Matka”), gospodarsko-praktycznym („Gospodyni Wiejska”, „Gospodyni Wiejska i Miejska”, „Dobra Gospodyni”), wychowawczo-społeczno-gospodarskim („Magazyn Mód i Nowości”, „Tygodnik Mód i Powieści”, „Bluszcz” - do 1905 r., „Kronika Rodzinna”), społeczno-kulturalnym („Bluszcz” - po roku 1905), literackim (kalendarz „Album Kobiecy”), modniarskim („Bazar”, „Penelope”, „Mody Paryskie”, „Nowe Mody Paryskie”), feministycznym („Kobieta”, „Świat Kobiecy”, „Ster”), społeczno-literackim („Świt”)

W zależności od profilu pisma prenumeratorki mogły w nim znaleźć atrakcyjne utwory literackie, informacje na temat bieżących zagadnień, artykuły o treści historycznej, estetycznej i obyczajowej, porady dotyczące sposobu prowadzenia gospodarstwa domowego, wiadomości geograficzne, przyrodnicze, medyczne, kulturalne oraz wiadomości o osiągnięciach ruchu kobiecego ${ }^{4}$. Zamieszczano w nich także artykuły $z$ dziedziny wychowania i kształcenia oraz bogatą ofertę ilustracji - krajobrazy, wizerunki architektury, dzieła malarskie, obrazki historyczne.

W omawianym okresie najbardziej trwale zapisały się wśród wydawnictw dla kobiet dwa tygodniki społeczno-literackie: „Bluszcz”5 oraz „Tygodnik Mód i Powieści”, a także początkowo dwutygodnik, a od końca 1900 r. tygodnik dla polskich rodzin katolickich „Kronika Rodzinna”. To ostatnie czasopismo znalazło się wśród omawianych magazynów kobiecych, gdyż kobieta - rodzicielka i wychowawczyni młodego pokolenia - zawsze zajmowała ważne miejsce w rodzinie i społeczeństwie. Przez blisko pięćdziesiąt lat wymienione czasopisma kształtowały opinie czytelniczek, wpływały na ich gusta ${ }^{8}$, wskazywały na „wszystkie zagadnienia niewieściego życia, wszystkie te ciche a ważne kwestie moralności rodzinnej, które

${ }^{3}$ Z. Z a I e sk a, Czasopisma kobiece w Polsce (materiały do historii czasopism). Rok 18181937, Warszawa 1938.

${ }^{4}$ Prasa polska w latach 1864-1918, red. J. Łojek, Warszawa 1976, t. 2, s. 48.

5 „Bluszcz” ukazywał się od roku 1865 aż do końca I wojny światowej oraz w okresie międzywojennym.

${ }^{6}$ W latach 1862-1871 czasopismo ukazywało się pod tytułem „Tygodnik Mód i Nowości Dotyczących Gospodarstwa Domowego”, od numeru 25 z 1871 r. jako „Tygodnik Mód i Powieści”, a w latach 1913-15 jako „Nasz Dom”.

7 „Kronika Rodzinna” założona w roku 1867 przetrwała do roku 1915.

8300 lat prasy polskiej 1661-1961, red. D. Kobielski, Warszawa 1961, s. 6. 
razem wzięte stanowią zacność i szczęście kobiety...”’. Stosunkowo krótko, gdyż tylko przez trzy lata (1884-1887), ukazywał się na rynku wydawniczym „Świt. Pismo tygodniowe ilustrowane dla kobiet". W 1887 r. wydawca zlikwidował tygodnik, gdyż ze względu na zbyt małą liczbę prenumeratorek zaczął on przynosić straty ${ }^{10}$. Dzieje „Świtu” były przestrogą dla redakcji innych czasopism i publicystów, aby nie głosili zbyt radykalnych poglądów w kwestiach społecznych, zwłaszcza dotyczących równouprawnienia kobiet.

Analizowany $w$ artykule okres obejmuje 50 lat. Jest sprawą oczywistą, że przez tak długi czas zmieniali się nie tylko redaktorzy i publicyści, lecz także lansowane poglądy i przypisywane poszczególnym sferom życia społecznego wartości. W związku z przeobrażeniami społeczno-gospodarczymi kraju, zmieniającymi się na przestrzeni lat warunkami ekonomicznej egzystencji rodzin oraz żyjących w tych ogniskach domowych kobiet, w kolejnych dziesięcioleciach omawianego okresu nieco inaczej kształtował się preferowany wizerunek idealnej niewiasty. Poza profilem czasopisma ważną rolę odgrywał również typ adresatek. Były nimi zarówno kobiety z warstw posiadających, jak i te, które utrzymywały się z pracy własnych rąk. Ich odmienne oczekiwania wyznaczały niejednokrotnie podejście redakcji do kwestii kształcenia dziewcząt, pracy zarobkowej kobiet oraz ich równouprawnienia.

\section{Adresaci wiodących magazynów kobiecych i rodzinnych}

„Bluszcz” adresowano do kobiet ze średnich i wyższych warstw społecznych, które sprzyjały umiarkowanej emancypacji. Poszukiwały one w tygodniku informacji na temat bieżących wydarzeń społecznych i kulturalnych. Redakcja "Bluszczu” stawiała sobie następujące zadania: wychowywać, uczyć i bawić. W takiej właśnie kolejności starano się je realizować. Zawartość pisma określał bardzo rozbudowany podtytuł: „Pismo tygodniowe ilustrowane dla kobiet obejmujące artykuły o wychowaniu estetycznym i moralnym, poezje, obrazki dramatyczne, oryginalne i tłumaczone, powieści, życiorysy znakomitych kobiet, kronikę wiadomości krajowych i zagranicznych, sprawozdania z literatury, muzyki i sztuk pięknych, utwory muzyczne i wiadomości z higieny oraz na osobnym dodatku rysunki mód, haftów, robótek wraz z opisem”. „Bluszcz” miał służyć kobietom radą i pomocą w ich zadaniach rodzinnych i społecznych. Problematykę wychowawczą poruszano najczęściej w artykułach wstępnych. W piśmie zamieszczano też recenzje literackie, teatralne, doniesienia ze świata nauki i sztuki. Ich odbiór wymagał pewnej wiedzy i doświadczenia z zakresu czytelnictwa.

„Tygodnik Mód i Powieści” kierowany był początkowo do warstw średnich, natomiast pod koniec XIX w. znaczne grono czytelniczek stanowiły kobiety,

\footnotetext{
${ }^{9}$ M. I In i c k a, Do Czytelniczek, „Bluszcz” [dalej: B] 1865, nr 1, s. 1.

10 S. L e we n t a I, Od Wydawcy „Świtu”, „Świt” [dalej: Ś] 1887, nr 152, s. 57.
} 
utrzymujące się z pracy własnych rąk. Były wśród nich przedstawicielki uboższego ziemiaństwa: modniarki, krawcowe, rzemieślniczki. Ich zainteresowania i potrzeby czytelnicze kształtowały się nieco odmiennie niż prenumeratorek „Bluszczu”"11. Zdaniem Jerzego Franke, adresatkami „Tygodnika Mód i Powieści” były niewiasty „o niewielkich ambicjach intelektualnych i nie rozbudzonych aspiracjach towarzyskich", które czerpały satysfakcję z zajęć domowych, a czasopismo traktowały „W utylitarny sposób: jako źródło praktycznej informacji, potrzebnej w gospodarskich pracach, a także jako środek zaspokojenia niezbyt wyrafinowanych potrzeb literackich"12. Dlatego też nie zamieszczano wówczas w piśmie artykułów programowych, nie poruszano kwestii równouprawnienia.

„Kronika Rodzinna” kierowała swoje przesłanie do rodzin katolickich, utożsamiając pojęcia Polak-katolik. Redakcja nakreśliła główny cel magazynu w następujących słowach: „służyć ku pożytkowi i umysłowej rozrywce rodzin, iżby młodzi znaleźć w niej mogli wskazówkę dróg życia i pracy, starsi zaś ułatwienie w trudnych obowiązkach opieki lub przewodnictwa rodziny"13. Niejednokrotnie podkreślano społeczno-religijny charakter pisma, którego zadaniem jest „stać na straży etycznym ideałom rodziny, [...] służyć rodzinom naszym nie tylko za pożyteczną rozrywkę, lecz i za dobrego doradcę, przyjaciela oraz za wskazówkę w różnorodnych zagadnieniach społecznych, zwłaszcza w sprawach wychowania"14. W artykułach wstępnych omawiano obowiązki pani domu oraz zasady racjonalnej organizacji jej pracy dla domu i rodziny. Wiele miejsca poświęcano sprawie wychowania dzieci. Jednocześnie zastrzegano: „mniej skorzy do nowości, do chwytania w lot pomysłów, próby doświadczenia nie mających, w przedmiotach społecznych i ekonomicznych damy pierwszeństwo urządzeniom i poglądom zgodnym z zasadami, na których dotychczasowy porządek społeczny spoczywa"15.

„Świt”, wydawany w połowie lat osiemdziesiątych XIX stulecia, miał być „organem ruchu umysłowego i praktycznej działalności”16 kobiet, „dążących do samoistnej pracy, do wiedzy, do stanowiska"17. Adresowany był do sfer posiadających - burżuazji, ziemiaństwa, zamożnej inteligencji oraz krawcowych, modniarek i innych pracownic, „pozostających w kręgu zależności od tej burżuazyjnej

${ }^{11}$ W 1888 r. w odpowiedzi, danej jednej z czytelniczek, zamieszczono następującą uwagę: „obok garści pracownic młodych, istnieją szeregi całe tych, które od nas wymagają rozrywki, posiłku duchowego, wskazówki praktycznej”. Zob.: Od Redakcji, „Tygodnik Mód i Powieści” [dalej: TMiP] 1888, nr 51, s. 2. Natomiast 3 lata później w zamieszczonym w piśmie liście czytelniczki przeczytać można: „prenumeratorki Tygodnika to przeważnie krawcowe albo magazynierki”. Ta sama autorka z żalem pisała: „bardzo mało osób czyta część literacką”. Zob.: [Maryusz], Nasze listy, TMiP 1891, nr 3, s. 22. Nie chodziło prawdopodobnie tylko o te konkretne zawody, ale o pewną kategorię kobiet, zarabiających na swoje utrzymanie.

12 J. F r a n k e, Wokół buntu i pokory: warszawskie czasopisma kobiece w latach 1905-1918, Warszawa 2000, s. 51.

${ }_{13}$ Od Redakcji, „Kronika Rodzinna” [dalej: KR] 1867, nr 5, s. 80.

14 Od Redakcji, KR 1900, nr 12, s. 379.

${ }_{15}$ Czego chce „Kronika”?, KR 1875, nr 1, s. 1.

16 Słowo wstępne, Ś 1884, nr 1, s. 1.

17 Od Redakcji, Ś 1885, nr 65, s. 193. 
sfery"18. Jego wydawcy zakładali popieranie żądania kobiet do równouprawnienia, lansowali więc zupełnie inny wizerunek niewiasty. Do najważniejszych postulatów programowych tygodnika należało dążenie do uzyskania przez kobiety równości obyczajowej, moralnej i cywilnej. Redakcja dokładała wszelkich starań, aby magazyn był „przewodnikiem tych wszystkich, co cierpią i walczą, by zdobyć sobie materialną niezależność" 19 .

\section{Obraz kobiety w czasopismach przeznaczonych dla płci pięknej}

W drugiej połowie XIX w. na skutek kryzysu ekonomicznego ziemiaństwa coraz więcej kobiet $z$ wyższych warstw społecznych musiało szukać pracy. Nie były do niej jednak przygotowane, brakowało im sił fizycznych, zdrowia, wytrwałości. Dodatkowo funkcjonujący w społeczeństwie stereotyp zabraniający pracy zarobkowej kobietom „dobrze urodzonym” pod groźbą złej opinii na temat ich statusu społecznego i materialnego utrudniał im znalezienie zatrudnienia. Kwestia ekonomiczna szczególnie ostro wystąpiła na ziemiach Królestwa Polskiego. W walce o niepodległość poległo wielu mężów i ojców, rząd carski za udział w powstaniach narodowowyzwoleńczych skonfiskował wiele majątków. Na skutek ukazu uwłaszczeniowego z 1864 r. szlachta musiała szukać nowych źródeł utrzyma$n^{2}{ }^{20}$. To wszystko spowodowało liczne migracje ludności do miast i zmianę pozycji społecznej wielu rodzin. Kobiety, zmuszone zarobić na utrzymanie własne i swoich dzieci, coraz częściej domagały się prawa do podjęcia pracy zarobkowej. Redakcje czasopism kobiecych nie mogły więc pominąć milczeniem tej ważnej kwestii, zmuszone były zająć określone stanowisko.

\section{„Bluszcz"}

Już w pierwszych latach istnienia magazynu jeden z publicystów podkreślał, że „ta, która jest matką i żoną, panią domowego ogniska i naczelniczką rodziny, nie powinna tracić czasu na próżne salonowe życie"21. Zalecano, aby w zyskanym w taki sposób czasie zajęła się w większym stopniu rodziną, bardziej zadbała o męża oraz o własny rozwój umysłowy - najlepiej poprzez czytanie

${ }_{18}$ T. C z a p c z y ń s k i, „Świt” pod redakcją Marii Konopnickiej. Materiały do twórczości, „Prace Polonistyczne" 1952, ser. X, s. 242.

19 Od Redakcji, Ś 1885, nr 65, s. 193.

${ }^{20}$ E. S t a s z y ń s k i, Polityka oświatowa caratu w Królestwie Polskim (od powstania styczniowego do I wojny światowej), Warszawa 1968, s. 15, 248.

21 O nowych zawodach dla kobiety, B 1870, nr 46, s. 349. 
odpowiedniej literatury ${ }^{22}$. Poza tym powinna zdobywać wiadomości pedagogiczne i przygotowywać się do wychowywania własnych dzieci ${ }^{23}$. Wskazane jest, aby była radosna, zadbana, pogodna i uśmiechnięta ${ }^{24}$. Jako jednostka samodzielna i odważna, miała stanowić dla innych wzór do naśladowania, przede wszystkim dla własnych dzieci i pozostałych domowników. Zalecano, aby w tym celu pokazywała „samotnym możność szlachetnego wytrwania o siłach własnych, słabym środek podniesienia się nad pokusę, utrzymania się ponad upadkiem"25. Ponieważ w następnych latach sytuacja ekonomiczna wielu rodzin pogarszała się, w kolejnym dziesięcioleciu w „Bluszczu” zwracano uwagę, że każda niewiasta musi pracować „według skłonności, a może według uzdolnień swoich”26. Jeśli ma rodzinę, jej zatrudnienia powinny się ograniczać do terenu gospodarstwa domowego. Przestrzegano jednocześnie czytelniczki: „niech tylko [...] sił ducha swego nie zatraca, a [...] życia serdecznego w sobie nie zabija", w zamian za to obiecywano, że „zawsze [...] ten wysoki dział szczęścia dostanie, który się nazywa ducha pogodą i ducha pokojem"27. Bronisław Chlebowski w artykule O wyrobieniu samodzielności charakteru u kobiet podkreślał duże znaczenie wytworzenia w sobie „pewnych stałych, wyższych celów życia i pewnych zasad, na których się mamy w dążeniu ku tym celom opierać"28. Samodzielność ta miała polegać na zrozumieniu sensu życia i umiejętności realizowania założonych celów. Każdy człowiek, a zwłaszcza kobieta, musi czerpać pokarm dla duszy z natury, nauki oraz dobrze pojętej religii, a tylko wówczas „może wyrobić i utrzymać zdrowie, siłę i harmonię wszystkich władz tej duszy"29. Potrzebuje jednak do tego pewnego światła nauki, która by ją oświeciła na drodze do realizacji postawionego sobie celu. Dlatego należy ją kształcić w sposób zupełnie odmienny od dotychczasowego. Maria Ilnicka pisała: „Wznieśmy umysłowy poziom kobiety, otwórzmy jej myślom widnokrąg szerszy, uszlachetnijmy jej gust przez poznanie arcydzieł niewątpliwych”, a wtedy „kobieta do pojęcia wyższych piękności podniesiona, wyższy polot myśli swojej nada i punkt umysłowego ciążenia gdzie indziej przeniesie" ${ }^{\prime 30}$. W omawianym okresie dość często odwoływano się do kobiecej duszy, podkreślając jej specyficzne właściwości, różniące ją od mężczyzny i jego wnętrza. M. Ilnicka zaznaczała, że „kobiecość [...] - to bynajmniej nie słodka minka, nie konwencjonalna niby łagodność słów doborowych, nie nicość myśli, nie małość uczuć, ale wielka i nie zmożona niczym siła kochania, poświęcenia się i ofiary dla przedmiotu drogiego, niemożność wyparcia się go i opusz-

${ }^{22}$ I. K r a j e w s k i, Stanowisko społeczne kobiety i odpowiednie temu jej wychowanie, B 1867, nr 43, s. 185.

${ }^{23}$ Żony ubogich mężów, B 1865, nr 6, s. 24.

${ }^{24}$ Tamże, nr 7, s. 28.

${ }^{25}$ M. II n i c k a, Słówko o emancypacji kobiet, B 1867, nr 10, s. 38.

${ }^{26}$ M. II n i c k a, Kwestia z kwestii, B 1870, nr 52, s. 407.

${ }^{27}$ Tamże.

${ }^{28}$ B. C h l e b o w s k i, O wyrobieniu samodzielności charakteru u kobiet. List do Panny ***, B 1871, nr 49, s. 373.

29 Tamże, s. 374.

${ }^{30}$ M. II n i c k a, Czytanie kobiety, B 1871, nr 6, s. 41. 
czenia"31. Za szczególnie ważne przymioty kobiety redaktorka uznała wytrwałość, ofiarność w pracy dla innych, głęboką miłość. Wzór osobowy kobiety z tego okresu był wciąż redukowany do przymiotów dobrej gospodyni - żony, matki, pani domu. Kobieta powinna być towarzyszką swego męża. Trzeba, aby „podniosła się umysłem do umysłu mężczyzny, aby mogła wejść w sferę myśli, w której on przebywa, ogarniać wzrokiem ducha taki sam rozległy horyzont, który on ma przed sobą, stać na takiej samej podniosłości duchowej, aby ich poglądy z jednakowego punktu widzenia brane, zgodnymi być mogły”32. Redaktorka „Bluszczu” przestrzegała, że jeśli mąż nie znajdzie w żonie nic więcej nad ładną lalkę, będzie szukał zrozumienia i rozrywek poza domem. Dlatego musi ona być „pojęta, zrozumiana, stojąca w życiu jako równa obok równego jej człowieka”, a nie cacko, „którym by dla zapomnienia trosk bawił się zmęczony”, nie karmelek, „którym by ocukrzył sobie gorycze życia" ${ }^{33}$.

Lata osiemdziesiąte przyniosły kolejny dogmat: żona człowieka pracującego musi zrozumieć ekonomiczne położenie własnej rodziny i współpracować z mężem w kierunku poprawy warunków życia wspólnoty ${ }^{34}$. Ideałem wyłaniającym się ze stronic pisma była: „kobieta dobra, kobieta szlachetna, która nie tylko uczciwie pracowitą być umie. Pojmuje ona położenie męża i współczuje z nim, troszczy się tkliwie o jego wygodę, o jego zdrowie ciężkimi warunkami pracy zarobkowej zachwiane, jest dla niego czułą, jest o niego staranną, i daje mu choć kilka chwil życia lepszych" ${ }^{35}$. Natomiast, jeśli kobieta jest inteligentna i otrzymała odpowiednie wykształcenie, powinna ponadto dbać o rozwój umysłowy swego towarzysza życia ${ }^{36}$.

Nawiązywano także do tradycji przeszłości, tej zupełnie dawnej, którą reprezentowały staropolskie matrony, i tej zupełnie bliskiej, zaledwie sprzed lat kilkudziesięciu, z okresu działalności entuzjastek z Narcyzą Żmichowską i Eleonorą Ziemięcką na czele. Podkreślano, że każda żona i matka powinna być taką entuzjastką ${ }^{37}$. Entuzjastka-żona nie będzie egoistką, potrafi kochać i myśleć szlachetnie. Jest żoną dobrą, stoi „silnie przy idei obowiązku”, ma „zapał cnoty”38. Nie przenosi dziecka ponad męża, „przez wyższe małżeństwa pojęcie, przez siłę tej dumy szlachetnej, która chce wszystkim swym obowiązkom zadość uczynić i żadnego ze swych praw nie utracić, towarzyszką, przyjaciółką, wspólniczką życia męża chce być i jest nią zawsze", nie próbuje zamknąć męża w ciasnym kółku domowych spraw, „ale sama do jego obywatelskiego, społecznego stanowiska myślą i uczuciem się wznosi, z nim i przez niego tam przebywa" ${ }^{39}$. Szlachetnego męża wspomaga, błądzącego napomina i cierpi. Mężowi zajętemu pracą społeczną i obywatelską zapewnia wypoczynek. Będąc matką,

31 M. I I n i c k a, Stanowisko Jerzego Eliot wobec kwestii kobiecej, B 1874, nr 52, s. 409.

32 M. I I n i c k a, Kobieta jako towarzyszka mężczyzny, B 1874, nr 2, s. 10.

33 M. I I n i c k a, Stanowisko..., s. 409.

${ }^{34}$ M. II n i c k a, Żony ludzi pracujących, B 1881, nr 15, s. 115.

35 Tamże.

36 Tamże, s. 116.

37 Nić tradycji, B 1882, nr 12, s. 89-90; nr 13, s. 97; nr 21, s. 161; nr 22, s. 169-170; nr 23, s. 177.

38 [M. I.], Nić tradycji, B 1882, nr 13, s. 97.

39 Tamże. 
entuzjastka pamięta, że „miłość macierzyńska sama przez się jeszcze cnotą nie jest, nie jest zasługą żadną, jeżeli nie podniesie się wyżej, nie uszlachetni polotem idealnym i gdy pozostanie w granicach popędu naturalnego" ${ }^{\prime 0}$. Kocha swoje dzieci, ale w każdym z nich „widzi przede wszystkim człowieka z jego szlachetnym przeznaczeniem w ludzkości, chowa je do przeznaczenia tego celów wysokich i poświęcając mu z zaparciem największym samą siebie, nie zaprze się przecież nigdy tego, co jest w niej godnością i obowiązkiem”41. Poczuwa się też do „kształcenia szlachetnej istoty ludzkiej”"2. Dobrą matką jest więc ta, „która dziecko swoje do wyższych w życiu przeznaczeń, do pewniejszego szczęścia i szlachetniej pojętej godności człowieka kształci - troskliwie, pracowicie, nieraz ciężko, z wielkim trudem, z wielkim sił wydatkiem wyrabia”33. Matka-entuzjastka „musi być nie tylko kochająca, ale i rozumną, musi mieć umysł wyższy i wykształcony”"44. Powinna być dla swych dzieci, zwłaszcza dla synów, „towarzyszką w dziedzinie myśli i pojęć wyższych, w świecie idei”"45.

Jeśli kobieta tak będzie postępować w codziennym życiu, to „podobna do swej siostrzycy staropolskiej moralnie, przewyższy ją tylko samoistnością w pracy, poczuciem własnej wartości, wiarą w pojęcia i zasady wyrobione w osobistym trudzie, a często i niezależnym bytem, stworzonym ciężką i długą pracą - przewyższy ją wreszcie wszystkimi cennymi doznaniami nowych pojęć i ideałów"46. Zalecano czytelniczkom:

Niech żona będzie względniejszą, wyrozumialszą, tkliwszą na położenie męża, niech wymaga mniej dla siebie i dzieci, które niech rozumniej, lepiej kocha, z głębszym zastanowieniem się nad ich przyszłością. Gospodyni niech się więcej do obowiązku pracowitości poczuwa, niech z jednej strony odrzuci formy życia przeżyte, z drugiej niech sięgnie myślą w tradycję naszą starą, gdzie znajdzie wzór pełen powagi i godności. [...] panna rozkwitająca do życia w domu rodzicielskim niech wie zawczasu, że jej najszczęśliwszym losem jest zostać pracowitą towarzyszką pracowitego człowieka, matką pracowitych dzieci ${ }^{47}$.

Przekonywano czytelniczki, że pracując głównie w domu, wychowując dzieci i dbając o domowników, więc „nie schodząc z gruntu kobiecości, nie odwracając się od domowych prac, od domowych kobiecych cnót, może tak młoda panna, jak matrona, żyć wyższym życiem ducha i uskrzydlona przez polot myśli wzniosłej, spełniać wszystkie te akta poświęcenia, męstwa, woli dzielnej, które opromienia życie ludzkie światłem z nieba odbitym”" ${ }^{4}$. Podkreślano również, że „kobieta wszystko znać może, niekiedy nawet powinna rozumieć - a nic to nie brudzi śnieżystości jej szaty; świadoma tajemnic wiedzy, świadoma pyłu i błota życia,

40 Tamże, nr 21, s. 161.

41 Tamże, nr 23, s. 177.

42 Tamże, nr 22, s. 169.

43 M. I I n i c k a, Siła i słabość uczucia, B 1885, nr 46, s. 361.

44 [M. I.], Nić tradycji, B 1882, nr 22, s. 169.

45 Tamże, s. 170.

46 W. P o d g ó r s k a, Tradycja i postęp w życiu naszych kobiet, B 1883, nr 36, s. 282.

47 Odpowiedzi na kwestionariusz rodzinny, B 1885, nr 28, s. 218.

48 M. I I n i c k a, Świat kobiety, B 1889, nr 42, s. 329. 
zawsze stać będzie wyniosła i majestatyczna, jeżeli posiada tę siłę moralną, jaką jest poczucie godności kobiecej"49.

W ostatnim dziesięcioleciu XIX w. wciąż podkreślano w „Bluszczu”, że kobieta powinna być dobra, rozumna i uczciwa. Niewiasta dobra jest „każdemu żywemu tworowi przychylna i węzłem sympatii serdecznej związana ze wszystkim, co żyje, czuje, co zatem może doznawać radości lub boleści, rozkoszy lub cierpienia"50. Kobieta rozumna nie pożąda rzeczy małych, pojmuje życie „w jego zadaniach wyższych, w jego dążeniach do celów tej cnoty, na której gruntuje się życie społeczeństw”51. Jeśli jest uczciwa - nie traci nigdy wiary w ludzkość. „Wierzy w człowieka - w cnotę, w dobro, piękno moralne"52. Bez względu na to, czy taka kobieta znajdzie się „u dołu czy na wyżynach społecznych, w dostatkach czy ubóstwie, zawsze osobiste tylko trudy i pracowite zabiegi dodają jej znaczenia, wartości i wpływu”53. Przekonywano też czytelniczki: „Nie po to powinno się za mąż wychodzić, by być szczęśliwą, tylko po to, by spełnić te obowiązki, które Bóg wówczas wkłada - szczęście to tylko przydatek i podarek Boży"54. Dlatego też kobieta musi być skłonna do poświęceń - dla dobra całego społeczeństwa i własnej rodziny.

Rolę dydaktyczną miały też odgrywać prezentowane na łamach czasopisma wizerunki kobiet. Za czasów redaktorstwa M. IInickiej w „Bluszczu” pisano o niewiastach zasługujących na uznanie ogółu społeczeństwa nie z powodu jakichś nadzwyczajnych zalet, ale właśnie dzięki sumiennemu wypełnianiu obowiązków. Jako wzory godne naśladowania przedstawiano osoby przeciętne, pozbawione wyjątkowych zdolności, ale skłonne do poświęcenia dla dobra innych, miłosierdzia, dobroczynności. Postaci te kreślono jako skromne i nieśmiałe, pogodzone z życiem i losem - traktowały życie jako powinność, oczekiwały nagrody dopiero po śmierci. Jedna z nich, Emilia Gosselin, chociaż nie była artystką ani wielką panią, „znalazła sobie uznanie i szacunek ogółu, który ją otoczył nimi dlatego, że była osobistością rozumną, dobrą i kochającą - że była kobietą zacną, której dusza miała w sobie wszystko, co u nas tradycyjnie stanowiło ideał cnót niewieścich: miała w czystej piersi ciepło i siłę"55. Za podobne zalety redaktorka „Bluszczu” chwaliła Apolonię Plewińską, przyjaciółkę Klementyny Tańskiej ${ }^{56}$. O holenderskiej poetce z XVII w. Marii Tesselschade pisała, że była to osoba szlachetna, „która już przed wiekami umiała zgodzić w sobie wszystko, co tylko jest dostojnością ducha ludzkiego w połączeniu ze świętym pojęciem obowiązku kobiety"57. Współcześni M. IInickiej przypisywali te właśnie cechy redaktorce „Bluszczu”, więc prawdopodobnie miał rację J. Franke twierdząc, że prezentowane osoby niekoniecznie takimi były w rzeczywistości, a być może przedstawiały jedynie „pożądane atrybuty niewiasty-obywatelki i w rezultacie modelowały

${ }^{49}$ W. P o d g ó r s k a, Tradycja i postęp..., nr 35, s. 274.

50 M. I I n i c k a, Kobieta dobra, B 1891, nr 17, s. 129.

51 [M. I.], Kobieta rozumna, tamże, nr 21, s. 162.

52 [M. I.], Kobieta uczciwa, tamże, nr 39, s. 305.

53 [M.], Z teki namiestniczej, B 1890, nr 52, s. 412.

54 Sienkiewicz o kobietach, B 1897, nr 52, s. 410.

55 Emilia Gosselin, B 1865, nr 18, s. 69.

56 M. I I n i c k a, Apolonia Plewińska, B 1973, nr 3, s. 17.

57 M. I I n i c k a, Tradycja i praca kobiet w Holandii, B 1874, nr 17, s. 129. 
rzeczywistość zgodnie ze stereotypem kobiety rodem z pism Tańskiej i Ziemięckiej"58. Kobiecie stawiano przede wszystkim wymagania etyczne - powinna doskonalić się moralnie i wypełniać powinności płynące z miłości bliźniego.

Dopiero pod koniec lat dziewięćdziesiątych XIX w. na łamach „Bluszczu” rozpoczęła się przemiana wzoru osobowego niewiasty - od kobiety wypełniającej swoje obowiązki głównie w domu, podległej mężowi, do tej, która stawała się coraz bardziej aktywna w życiu społecznym i zawodowym, a dostrzegając przy tym wokół siebie niesprawiedliwość i społeczną krzywdę, próbowała zaradzić złu. $\mathrm{Na}$ skutek zmian personalnych w redakcji „Bluszczu” - obowiązki redaktora w $1897 \mathrm{r}$. objęła Józefa Bąkowska, a po roku 1905 Zofia Seidlerowa - zmieniło się zapatrywanie tygodnika na rolę i zadania kobiety w społeczeństwie. Niewątpliwie także nasilenie ruchu emancypacyjnego na ziemiach polskich, czego przejawem były organizowane już w ostatnich latach XIX w. tajne, a po 1905 r. jawne zjazdy kobiet polskich ze wszystkich trzech zaborów, miało wpływ na zmianę stanowiska redakcji czasopisma w kwestii kobiecej. Pojawiły się wówczas nowe postulaty: kobieta „powinna być zainteresowaną wszystkimi sprawami społeczeństwa, przejąć się poszanowaniem i uznaniem prawd naukowych, sprostować swój zmysł intuicyjny, zbogacać umysł gruntownymi wiadomościami i doprowadzać go do równowagi ze skarbami uczuć swego serca” ${ }^{9}$. W 1902 r. Z. Seidlerowa pisała: „Kobieta, która umie zrównoważyć w sobie zalety umysłu i serca z hartem ducha i siłami fizycznymi - pożyteczną zaś dla rodziny i społeczeństwa pracę z pieczą o dobro domowego ogniska [...] to ideał kobiety naszej doby"60.

Kobieta powinna odznaczać się silnym charakterem: „niech nie będzie tą słabą, chwiejną istotą, podobną do roślinki wątłej, którą lada wicher łamie, słabszą fizycznie od mężczyzny, niech mu nie ustępuje hartem ducha, lecz wraz z nim stoi

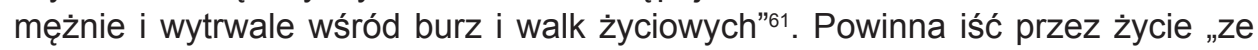
sztandarem ideałów, ze sztandarem dobra, wiary i męstwa”, „niech podnosi upadłych, pociesza zwątpiałych, rozdając dokoła róże dobra, światła i ciepła. Niech ma siłę wyzuć się ze swego «ja», poświęcić się dla społeczeństwa"62. Zrozumiano wówczas, że duchowo rozwiniętej kobiecie nie wystarcza do pełnego szczęścia "ciche domowe ognisko, ciepłe rodzinne gniazdko, istnienie wyłącznie domowi i mężowi poświęcone. Kobieta duchowo dojrzała pragnie i ma prawo czuć, że jest czymś sama w sobie i sama przez się, że potrafi czerpać najwznioślejsze zadowolenie w pracy, nauce czy sztuce, w niesieniu swych usług wedle sił i możności ku ogólnemu, społecznemu dobru”63. To oczywiście nie oznacza, że przestanie być dobrą żoną i matką. Nie będzie jednak wypełniać swych domowych obowiązków „poświęcając się” dla męża i dzieci, raczej zacznie się kierować miłością

\footnotetext{
${ }^{58}$ J. F ra n ke, Polska prasa..., s. 135.

59 J. L u o r b e t, Zadanie kobiety w przyszłym społeczeństwie, streściła P. Grodzińska, B 1900, nr 10, s. 74.

60 Z. S e i d I e r o w a, Kobieta naszej doby, B 1902, nr 33, s. 386.

61 Nasz kwestionariusz panieński, tamże, nr 39, s. 463.

62 Tamże.

${ }^{63}$ Z. S e i d I e r o w a, O wychowaniu dziewcząt podług Henryka Morione, B 1903, nr 5, s. 50.
} 
i dobrą wolą ${ }^{64}$. Nie straci też swego powabu i uroku ${ }^{65}$. Niewątpliwie „będąc szczerą i prawdziwą, będzie dumną z siebie, ze swej wartości, i wymagać będzie wielkiego uczucia, bo jeszcze większym obdarzać będzie zdolna"66. Trzeba jednak pamiętać, że „kobieta tylko sama przez się wzrastać może - niechaj się bada, pracuje, dąży i myśli”' ${ }^{67}$. Zażądano dla kobiet prawa dostępu do nauki na wszystkich poziomach. „Nowa” kobieta powinna być umysłowo wykształcona, moralnie doskonała, specjalnie i fachowo wykształcona, mieć zupełnie równe z mężczyzną prawa, być równą mężczyźnie. Powinna też szanować przeszłość, nie zrywać z Kościołem, respektować prawa społeczne, pracować dla dobra kraju i kierować się zawsze tym, co szlachetne ${ }^{68}$. Musi też być „członkiem społeczeństwa takim, jak mężczyzna, może o większych od niego nawet prawach, gdyby to było możliwe, ciążą na niej bowiem obowiązki matki. Każda gałąź nauki i pracy powinna być dla niej dostępna"69. Tylko taka niewiasta potrafi sprostać nałożonym na nią zadaniom i wychowa Ojczyźnie - człowieka.

Po 1910 r. w „Bluszczu” przypominano czytelniczkom, że kobieta nie może rządzić tylko w rodzinie i „chować głowy jak struś za domowy węgieł” - „jej zadaniem jest uzdrowienie życia publicznego, jej celem aby to życie właśnie stało się rodziną, gdzie walk i kłamstwa, i targaniny, i zepsucia takiego jak dziś nie będzie”. Tym bardziej, że wykonywanie zawodów lekarki, obrońcy, posła, nie wyklucza uczuć obywatelskich. Uspokajano jednocześnie czytelników:

Możemy być spokojni, kobieta, która życie poświęci pracy, którą ta praca nauczy społecznego ładu i obowiązku, będzie matką, nie będzie może sama niańczyć swych dzieci i wprawiać ich własnoręcznie do robótek freblowskich, ale zasady życia potrafi im dać, bo te z doświadczenia swego trudu zaczerpnie, ale będzie dzieciom siłą, będzie ich rozumem, będzie przykładem jak żyć, pracować i poświęcać się trzeba ${ }^{70}$.

Wskazywano, że kobieta powinna być „współdziałającą i współczującą cząstką wielkiego organizmu narodowego, obywatelką odpowiedzialną za dalszy jego byt i rozwój"71. Miała być również misjonarką odrodzenia etycznego ${ }^{72}$. Nawiązywano też czasem do wzoru osobowego kobiety - kapłanki domowego ogniska, jednak czyniono to głównie po to, aby wskazać, że pełnienie tej tylko funkcji nie wystarczy, a samo stwierdzenie jest anachroniczne. Choć szanowano tradycję i dokonania przeszłości, wskazywano czytelniczkom przyszłość.

Niewiasta, aby sprostać stawianym przed nią zadaniom, wciąż musi się dokształcać, „tak dla utrzymania swej roli w małżeństwie na stopie umysłowej towarzyszki mężczyzny, jak dla intelektualnej równości z coraz wyżej kształcącymi się

64 Z. S e i d l e r o w a, Żona, tamże, nr 9, s. 100.

${ }^{65}$ [Matka-Polka M.R.S.], Jaka kobieta nie starzeje się i nie traci nigdy swego wdzięku?, tamże, nr 31, s. 364.

66 [S.], Kobieta przyszłości (Według Ellen Key), B 1905, nr 1, s. 1-2.

67 Tamże, s. 2.

68 Nasz kwestionariusz męski, tamże, nr 41, s. 474.

69 C. W a l e w s k a, Kobieta przyszłości, B 1908, nr 30, s. 340.

70 N. J a s t r z ę b s k a, Dawne teorie a nowa praktyka, B 1913, nr 17, s. 183.

71 [D-rowa Kosmowska], Nasze panny, tamże, nr 20, s. 212.

72 M. Cz. P r z e w ó s k a, W Przyszłość: w obronie prawa moralnego, B 1911, nr 5, s. 45-47. 
w miarę dorastania dziećmi. [...] Pierwotne wykształcenie swoje powinna ciągle kompletować w taki sposób, aby miała skąd czerpać na każde zapotrzebowanie umiejętność inteligentnego pojmowania i wykonywania wszystkiego, co w danej chwili wejdzie w jej zakres życiowy"73.

\section{„Tygodnik Mód i Powieści”}

W „Tygodniku Mód i Powieści”, podobnie jak w „Bluszczu”, podkreślano, że kobieta najpierw powinna wypełnić obowiązki wynikające z rodzinnego życia, a w czasie wolnym zająć się pracą umysłową. Musi dużo czytać i rozwijać się umysłowo, gdyż naczelniczki rodziny powinny być:

[...] myślące, ukształcone, pracowite, aby rozumiały zadanie życia i umiały tak rozłożyć swe gospodarskie i umysłowe zajęcia, iżby nie miały czasu na nudy, umiłowały domowe ognisko, aby zostawszy matkami, umiały same uczyć lub przynajmniej przewodniczyć nauce swych dzieci, zająć się i mówić o czymś więcej jak o modach, strojach, zabawach i tańcu lub choćby nawet o gospodarstwie, aby jak tego żąda Pismo święte, umiały być dla męża towarzyszką, pociechą, pomocą, a nawet i radą, jednym słowem - aby pojmowały i odpowiadały wzniosłemu swemu posłannictwu ${ }^{74}$.

Twierdzono, że kształcić umysł mogą nawet te, które mają małe dzieci. Natomiast zwalniano $z$ tego obowiązku kobiety zmuszone zarabiać na swe utrzymanie pracą własnych rąk dowodząc, że one rzeczywiście mogą na to nie mieć czasu ${ }^{75}$. Wskazywano również, że wady kobiece, takie jak: płochość, lekkomyślność, zalotność, wynikają z wadliwego wychowania dziewczą ${ }^{76}$. J. Belejowska już pod koniec lat sześćdziesiątych przekonywała, że przedstawicielki płci pięknej powoli zbliżają się do tego ideału: „Dzięki niebu dziś już kobieta XIX w. jest panią siebie, swej duszy i swego sumienia, wyrobiła już w sercu swoim szlachetne poczucie godności i dumy, jakimi ją przejmuje pojęcie wielkich swoich i świętych przeznaczeń, niechże je na wieki przechowa w swej duszy"77.

W latach siedemdziesiątych publicyści wciąż podkreślali, że kobiecie potrzebne są przede wszystkim zalety dobrej gospodyni, takt i zręczność, prostota, dobry smak, rozum, grzeczność i wytworne obejście. „Zatrudnienia gospodarskie, roboty kobiece i talenta na przemian ją zajmują: ta sama ręka zarówno wprawnie bierze się z kolei do pióra, do pędzla i do igły"78. Jej obowiązki skupiają się na rodzinie i właśnie temu powinna cała się oddać. Światu może się udzielać w czasie wolnym - będzie to dla niej dobrą rozrywką ${ }^{79}$. Kobieta powinna być pierwszą mistrzynią i nauczycielką rodziny. Ona jest odpowiedzialna za rozwój dziecka.

73 J. Te r p i, Książka o kobiecie nowej, B 1910, nr 13, s. 141.

74 Nauka i praca jest obowiązkiem kobiety, „Tygodnik Mód i Nowości Dotyczących Gospodarstwa Domowego" [dalej: TMiN] 1868, nr 15, s. 1. Zob. też przyp. 6.

75 Tamże.

76 Tamże, nr 14, s. 1.

77 J. B e l e jo w s k a, Kobieta w XIX w. (Prelekcja p. E. Polettau), TMiN 1869, nr 23, s. 2.

78 E. H i p p e a u, Ekonomia domowa, TMiN 1871, nr 8, s. 4.

79 Tamże, nr 5, s. 3. 
„Poświęcenie, cierpliwość, zaparcie się, stałość w celach, godność, moc i odwaga, oto są macierzyństwa konieczne zalety. Matka rodziny stanowi o jej losie: panowanie jej wszechwładne, wszystkie więc cnoty panujących winna posiadać" 80 .

Kobieta oświecona, mieszkająca na wsi, poza obowiązkami w domu i w rodzinie powinna także zająć się najbliższym otoczeniem, szerzyć oświatę wśród niższych warstw społecznych. E. Hippeau tak określał jej zadania:

[...] nie pozostanie obcą żadnemu z pobliskich mieszkańców. [...] Rozprasza przesądy, przekonywa o wartości ulepszeń w gospodarstwie, zbliża poróżnionych, godzi waśnie, zbłąkanych na dobrą naprowadza drogę, pracuje nad wykorzenieniem zabobonnych wyobrażeń i mniemań niedorzecznych, których jeszcze tak wiele napotkać po wsiach można. Przykłada się czynnie do wszelkich stowarzyszeń i usiłowań w celu szerzenia oświaty, nauki lub ratowania nędzy ${ }^{81}$.

Jeśli tylko właściwie rozplanuje swoje zajęcia, znajdzie czas na wszystko. Jako kobieta światowa „umie wszędzie zastosować się do przyjętych zwyczajów, do wymagań, a nie wygląda to, jak gdyby chciała dawać nauczki tym, co ich nie znają. Ściśle dopełniając swoich powinności, przewodnicząc wychowaniu swych dzieci, znajdzie czas i na religijne obowiązki, i na uczynki miłosierne, i na utrzymanie stosunków przyjacielskich i światowych - bo w życie swoje wprowadziła zasady porządku, systematyczności i przezorności, które przewodniczyć winny wszelkim rządom”82. Jeśli więc potrafi być „towarzyszką i wspólniczką męża, staranną matką i ochmistrzynią swoich dzieci, a jednocześnie ozdobą towarzystw przez swój rozum, talenta i miłe przymioty, dobrą, litościwą i miłosierną przy łożu chorego i w izdebce nędzarzy - takiej kobiecie należy się cześć i poszanowanie"83. I takie właśnie kobiety - zdaniem E. Hippeau - można spotkać w codziennym życiu.

W latach osiemdziesiątych w „Tygodniku Mód i Powieści” odnotowano zmianę w zachowaniu wielu młodych Polek. Z nostalgią więc wspominano postać dawnej szlachcianki, która odznaczała się wieloma pozytywnymi cechami:

Pełna prostoty, szczera, prawdziwie pobożna i głęboko religijna, skromna, czytała jedynie poważne, moralne i budujące książki, nie rozprawiała o emancypacji i równości praw, ale za to niejednokrotnie wywierała zbawienny wpływ na umysły i otoczona czcią ogólną, używała przywilejów wyższych od praw mężczyzny. Nie popisywała się znajomością nauk ścisłych i filozofii, ale jakiż to był zdrowy i głęboki rozum przy owej prostocie! Jakże wysokie miała pojęcie o obowiązku, co za charakter i siła moralna! Jak odczuwała piękne zasady prawdziwie wzniosłego życia, jak umiała wychowywać dzieci, jak umiała być dla nich świętością! ${ }^{84}$.

Wówczas były to w pełnym tego słowa znaczeniu „kapłanki domowego ogniska, matki, żony i obywatelki”. Z żalem dodawano: dziś jest inaczej. Pojawiały się jednak także głosy bardziej optymistycznie nastawionych publicystów, piszących:

${ }^{80}$ E. H i p p e a u, tamże, 1870 , nr 33, s. 6.

81 Tamże, nr 39, s. 8.

${ }^{82}$ E. H i p p e a u, tamże, 1871, nr 8, s. 4.

83 Tamże.

${ }^{84}$ Z kraju i zza granicy, TMiP 1882, nr 28, s. 332. 
„Kobiety nasze potrafią oszczędzać i pracować, bo skłania je do tego obowiązek, przekonanie, przywiązanie do rodziny i do ziemi ojczystej"85.

W ostatnim dziesięcioleciu XIX w. w „Tygodniku Mód i Powieści” główne zadania niewiasty wciąż sprowadzano do pracy w domu i dbania o wygody męża. Obawiając się jednak utraty ewentualnych prenumeratorek, nastawionych bardziej radykalnie, odcinanie się od postulatów emancypacji tłumaczono w sposób następujący: „Tygodnik był i pozostanie na przyszłość pismem, które najtroskliwsza matka dorosłej i dorastającej córce bez obawy dać może w rękę" ${ }^{\prime \prime 6}$. Zastanawia fakt, że właśnie w tym okresie czasopismo cieszyło się szczególną poczytnością, zdobyło największą liczbę prenumeratorek. Prawdopodobnie znaczna część czytelniczek czasopism kobiecych nastawiona była raczej konserwatywnie wobec wszelkich zmian. Problematyka rodzinna oraz kwestie związane z wychowaniem i nauczaniem dzieci wydawały się więc najbardziej bezpieczne.

W latach dziewięćdziesiątych jedna z publicystek zauważyła, że coraz więcej kobiet szuka w małżeństwie „stanowiska i życia bez troski”" d dlatego po $1900 \mathrm{r}$. postawiono przed niewiastą kolejne istotne zadanie: powinna dbać o duszę rodzinnego domu, gdyż tylko wtedy będzie on właściwym miejscem wychowania młodego pokolenia ${ }^{88}$. Podkreślano również, że każda kobieta "może być kapłanką, byle w swej piersi strzegła pilnie świętego ognia, źródła wiekuistego ciepła i światła, które powinna rozsiewać dokoła”89. Wówczas też na łamach pisma pojawiła się teza o nierówności płci i braku dyspozycji kobiety do studiów wyższych oraz do obejmowania wielu stanowisk zawodowych. Wszystkie wyższe stanowiska społeczne i zawodowe rezerwowano głównie dla mężczyzn ${ }^{90}$. Takie przedstawienie problemu nie zniechęciło jednak czytelniczek.

Po 1910 r. również w „Tygodniku Mód i Powieści” niewiasta zaistniała w nowej roli - jako działaczka społeczna ${ }^{91}$. Z ogromnym przekonaniem podkreślano: „Wielką siłę w życiu daje kobiecie samodzielne stanowisko i praca na nim. [...] Tylko praca może wybawić kobiety od tej biedy moralnej, w jakiej żyją"92. Odwołując się do przykładu entuzjastek z pierwszej połowy XIX w. pisano:

Dziś ten typ kobiet, wyczuwając tętno potrzeb krajowych, przykłada ręce do społecznego dorobku, zakłada sklepy współdzielcze, urządza odczyty w sprawach obchodzących żywo ogół myślących, tworzy czytelnie, pralnie, uczelnie, szerzy kulturę, a działając odśrodkowo, promieniami rzucanymi na zewnątrz, nie zubaża domu, lecz go bardziej jeszcze ogrzewa ${ }^{93}$.

${ }^{85}$ Na ciężkie czasy, TMiP 1885, nr 19, s. 146.

${ }^{86}$ Od redakcji, TMiP 1896, nr 52, s. 409.

${ }^{87}$ [P.], Wyżej. Kilka słów na temat: Kobieta w rodzinie, TMiP 1891, nr 1, s. 4.

88 Z. D ę b i c k i, Dom, TMiP 1908, nr 6, s. 1.

${ }^{89}$ [Z. S.], Carmen Sylva „Kobiety”, TMiP 1909, nr 24, s. 1.

90 [T. M.], Ze spraw społecznych, TMiP 1901, nr 5, s. 38; [K.], Z życia kobiety, TMiP 1903, nr 11, s. 126-128; [T. M.], Jeszcze jeden głos w kwestii kobiecej, TMiP 1895, nr 35, s. 278; t e n ż e, Bankructwo intelektualizmu kobiecego w opracowaniu profesora I. Jussieu, TMiP 1903, nr 25, s. 296.

91 [D-rowa Kosmowska], Działaczki społeczne, TMiP 1910, nr 1, s. 8.

${ }^{92}$ A. O p o I s k a, Matka, TMiP 1911, nr 36, s. 5-6.

${ }^{93}$ E. Ż m i j e w s k a, Żony społecznice, TMiP 1912, nr 1, s. 2. 
Nie oznaczało to jednak przyznania kobiecie praw równych z tymi, z jakich korzystali mężczyźni. Jej zadania poza rodziną wiązano głównie z działalnością społeczną.

\section{„Kronika Rodzinna”}

W „Kronice Rodzinnej” w początkowym okresie jej istnienia podkreślano ważność następujących cech charakteru, pożądanych dla każdego człowieka, więc także dla pani domu: „zacność charakteru, podniosłość ducha, gruntowna bogobojność, wyższy nastrój umysłu"94. Adam Goltz przekonywał czytelniczki:

Nic tak kobiety nie czyni piękną, jak czynność ducha, niezmordowana pracowitość, a umiejętność i szykowność w spełnianiu wszelkich obowiązków, jakie na nią z kolei spaść mogą. A nic znowu nie ubliża tak kobiecie, jak niedołężna bierność, która sama nie wie, co z swoim czasem i osobą swoją począć, która nie umie z głębi ducha swojego zaczerpać warunków szczęścia i samodzielności, ale je szukać musi, dla wewnętrznej swojej próżni, w strojach, rozrywkach, balach itp. ${ }^{95}$

Oczywiście każda niewiasta powinna się kształcić, gdyż od Stwórcy otrzymała do tego zdolności, a Bóg „nic na próżno nie daje”96, ale zdobywana przez nią wiedza powinna służyć lepszemu wypełnianiu obowiązków. Kobieta jest też „szafarką łask i darów Bożych”, musi więc je odpowiednio wykorzystać „umiejętną gospodarnością, trafnym zarządem; rozumną i dobrze skierowaną pracą"97. Jest za to odpowiedzialna przed samym Stwórcą.

Kolejne dziesięciolecie nie przyniosło właściwie żadnych zmian w postrzeganiu roli i zadań niewiasty. Wciąż sprowadzano je tylko i wyłącznie do działalności w rodzinie i dla jej dobra. Wynikało to z przekonania, że kobieta w rodzinie miała do spełnienia niezmiernie istotną rolę. Podkreślano, że do jej obowiązków należy: strzec, koić cierpienie, łagodzić niepokoje i nieporozumienia, usuwać trudności. Dlatego niewiasta chrześcijańska powinna być odważna, nawet cierpiąc sama musi umieć pocieszać innych, pamiętać o uboższych. Zalecano: niech spełnia obowiązki towarzyskie, zna interesy odnoszące się do dobra męża i rodziny, potrafi się wznieść „na wyżyny świata intelektualnego, a dusza jej jest przybytkiem wzniosłych i szlachetnych uczuć"98. Jeśli będzie zajęta od rana do wieczora czymś pożytecznym, nie będzie próżnowała i da dobry przykład innym ${ }^{99}$.

W „Kronice Rodzinnej” powoływano się też na wyższość moralną niewiast i wynikającą stąd możliwość ich oddziaływania na pozostałych członków rodziny ${ }^{100}$. Pociąga to jednak za sobą konieczność odpowiedniego wychowania kobiet

\footnotetext{
94 A. G olt z, Budżet domowy, KR 1867, nr 2, s. 18.

95 A. G olt z, Reforma w wychowaniu kobiet $i$ w użyciu ich czasu i pracy, KR 1869, nr 7, s. 99.

96 [O*], O uczoności kobiet, tamże, nr 8, s. 113.

97 A. Golt z, Reforma..., tamże, nr 10, s. 148.

98 K. P o m i a n, Kilka oderwanych myśli o rodzinie, kobiecie i małżeństwie, KR 1873, nr 30, s. 1-2.

99 Tamże.

100 [M. I.], Słówko do młodych matek, KR 1871, nr 15, s. 227.
} 
„mężnych, silnych duchem, silnych wiarą, silnych nadzieją i miłością, silnych zamiłowaniem pracy i obowiązku, słowem podniesionych w całej pełni do stanowiska mężnych niewiast chrześcijańskich"101. Niewątpliwie ważna rola przypada w tym względzie ojcom i mężom, którzy często „zarzucają kobietom płochość, lekkomyślność i wad innych wiele"102, a nic nie robią, aby to zmienić. Muszą więc poczuć się bardziej odpowiedzialni za swoje córki oraz żony i zrobić wszystko, aby potrafiły one odpowiedzieć swojemu powołaniu i godności. Wszak „prawdziwe wykształcenie, połączone z chrześcijańskim wychowaniem [kobiety - B.K. -W. ] otaczające jednocześnie jej zdanie, myśl, sąd i wolę, otwierające przed nią skarby wiedzy, uzdolni ją dopiero do zadośćuczynienia wymaganiom zajętego stanowiska, pozwoli jej zająć ważniejsze jeszcze, wywalczy jej szacunek i miłość męża, uszanowanie synów, ustali byt rodziny, na wspólności zdań, uczuć, prac, myśli i celów opartej"103. Pracować nad własnym udoskonaleniem powinny też same kobiety, „ażeby zawsze stać na wysokości swego stanowiska [...] być uosobieniem wszystkiego, co dobre, piękne, doskonałe"104. Za wzór do naśladowania stawiano czytelnikom „prababki pobożne, które umiały niezaprzeczenie, gospodarnie i zasobnie kierować czeladką, apteczką, lamusem i spiżarnią"105. Ponieważ - pisano - dawne nasze kobiety były praktyczne w zarządzie majątkami, miały znajomość stosunków społecznych, „z nieomylną wiarą w przyszłość, zwróciliśmy oczy nasze w obraz dawnej rządnej i rozumnej niewiasty, która najserdeczniejszy brała udział w pracy społecznej, nie zatracając tej najpiękniejszej wyłącznej cechy, którą Twórca namaścił jej skronie"106.

Zdaniem jednego z korespondentów „Kroniki Rodzinnej”, żona i matka powinna:

1. Być duchem opiekuńczym, oddziaływującym duchowo, jakby magnetycznie, miłością, słodyczą, poświęceniem, pracowitością na całe swoje otoczenie [...], 2. Gospodarnością, rządem i oszczędnością stać się ważnym czynnikiem w ekonomicznym ustroju społeczeństwa [...], 3. Wychowywać dla Boga i kraju młode pokolenie w cnocie i pracy ${ }^{107}$.

natomiast inny skupił się na oddziaływaniu żony na męża:

[...] wpływ kobiety rozumnej i światłej może być jedynie dobroczynnym. Wywierać go zacznie najpierwej na męża swego, podtrzymując jego siłę moralną, gdy upada na duchu, bystrością sądu dopomagając mu w roztrząsaniu każdej ważniejszej sprawy, poczuciem piękna wskazując wszystko, co dobre i szlachetne, surowością zaś zasad zgodnych z czynem i pełnym miłości pobłażaniem zwracając na drogę obowiązku. Mąż światły, który nie mógł dotąd dzielić się z żoną myślą i poważną rozmową, znajdzie w niej teraz pilną współpracowniczkę na polu wiedzy, towarzyszkę i przyjaciółkę, której powierzy wszystkie swe myśli i uczucia; wtedy dopiero małżeństwo stanie się owym doskonałym dusz zjednoczeniem, jakim je chciał widzieć Zbawiciel"108.

101 Wpływ wzajemny, KR 1870, nr 22, s. 340.

102 Tamże.

103 [A. B.], Kilka słów o wychowaniu i kształceniu niewiast naszych, przez A.D., KR 1872, nr 8, s. 7.

104 [M. I.], Słówko do młodych matek, KR 1871, nr 15, s. 227.

105 Z Zawiśla, KR 1877, nr 7, s. 103.

106 W. C h o m ę t o w s k i, Stanowisko praktyczne dawnych niewiast, KR 1872, nr 6, s. 84.

107 Z Zawiśla, tamże.

108 [X.], Wiadomości literackie. Wychowanie kobiety i stanowisko jej w społeczeństwie, KR 1875, nr 1, s. 16 . 
Coraz częściej akcentowano więc potrzebę rozwoju umysłowego kobiety, ale ostatecznym celem tego rozwoju miała być umiejętność zrozumienia i wspieranie mężczyzny.

Pomimo idealizowania pozycji kobiety $w$ rodzinie, zdawano sobie również sprawę z tego, że nie wszystkie dziewczęta wyjdą za mąż i urodzą dzieci. Radzono więc młodym panienkom "doskonalić się wszechstronnie, zgodnie ze swymi zdolnościami i wyrabiać w sobie samodzielność", gdyż to wszystko nie pozbawi je wdzięku, łagodności, słodyczy, a umożliwi niezależną egzystencję ${ }^{109}$. Za szczególnie ważną dla wszystkich kobiet, zarówno zamężnych, jak i samotnych, uznano cnotę męstwa, ponieważ życie jest bojowaniem, a „męstwo w kobiecie to największy skarb dla męża, którego mężna niewiasta jest otuchą i podporą wśród zmiennych i dotkliwych losu kolei”'110. Istotne są również siła ducha, wiara, nadzieja i miłość, zamiłowanie w pracy i w obowiązku. Taki jest wzór „mężnych niewiast chrześcijańskich”"111. Pocieszano też czytelniczki, że chociaż „w kobiecie siły wątlejsze, mniej fantazji twórczej i mniej sądu ścisłości, ale za to skarby uczucia i pojęcie, i ukochanie doskonałości duchowej, i cześć przeszłości, i wiara w przyszłość, pobłażanie i miłość dla słabych i wątłych, i cierpiących"112. Dlatego nie powinny się martwić własną niedoskonałością, ale raczej dziękować Bogu za to, co otrzymały. W latach dziewięćdziesiątych ponownie powrócono do twierdzenia, że kobieta poza zaletami serca i umysłu musi mieć wiedzę, wykształcenie umysłowe, żeby mogła być towarzyszką swego męża i wychowawczynią dzieci, musi utrzymywać kontakt z szerszym środowiskiem, nawiązywać stosunki towarzyskie ${ }^{113}$.

Po 1900 r. ponownie przypomniano czytelniczkom przymioty, które powinna posiadać każda dobra gospodyni: pobożność, zamiłowanie do porządku, czystość, pracowitość i oszczędność ${ }^{114}$. Musi odpowiedzialnie przygotować się do pracy $\mathrm{w}$ domowym gospodarstwie ${ }^{115}$. Jako matka stanowi przykład dla swego potomstwa, dlatego powinna „być zawsze równą, jednakowo uprzejmą, cierpliwą, łagodną”116. Jako żona i matka „powinna być podporą i dźwignią rodziny, a przez swoje poświęcenie się osłodą i bóstwem jej opiekuńczym. Zadaniem kobiety w małżeństwie jest podzielać $z$ mężem brzemię interesów, a w wielu razach dopomagać mu w pracy. Małżonka powinna brać udział w rozrywkach, ale zarazem i w troskach męża, powinna w rodzinie zająć wysokie stanowisko pomocnicy i doradczyni męża"117. Musi wspierać męża, dodawać mu odwagi i otuchy, zachęcać do wykonywania rzeczy dobrych.

Po 1910 r. nic się nie zmieniło w podejściu redakcji i publicystów „Kroniki Rodzinnej" do roli i zadań kobiety - wciąż sprowadzano je do obowiązków w rodzinie:

${ }^{109}$ [A. B.], Kilka słów..., tamże, nr 9, s. 136.

110 Z Zawiśla, tamże.

111 Tamże.

112 A. D z i e d u s z y c k a, Książka młodej kobiety, KR 1881, nr 3, s. 68.

113 Z działu wychowania, KR 1892, nr 18, s. 558.

114 Jak rządzić domem, KR 1902, nr 3, s. 12.

115 Tamże.

116 L. Cz.], Jaką powinna być żona i matka, KR 1901, nr 48, s. 948.

117 [X.F-S.], Żona, KR 1903, nr 5, s. 106. 
[...] przeznaczeniem kobiety jest wyjść za mąż, umilić temu towarzyszowi swemu życie, dopomagać mu w pracy, ułatwić ciężką egzystencję, oraz dać życie nowym osobnikom i wychować je na dobrych obywateli kraju. Jest to zadanie bardzo ciężkie, ale czegoż kobieta dzielna, rozumna i głęboko pojmująca swoje przeznaczenie społeczne, nie pokona i nie dokona przy dobrej woli i odpowiednim przygotowaniu ${ }^{118}$.

Jednocześnie ubolewano, że matki rzadko przygotowują córki do czekających je w życiu obowiązków. Tymczasem najlepszym posagiem panny są: pogoda, uśmiech, oszczędność, zaradność, łagodność, uprzejmość, zadowolenie, praca, czyste sumienie, prawość, wierność, schludność, czystość, szlachetność, samopoznanie, przezorność, doświadczenie życiowe, rozsądek, spokój, wytrwałość, przywiązanie, przyjaźń, dobroć serca - „taki posag jest najlepszą rękojmią szczęścia małżeńskiego"119.

\section{„Świt”}

Redakcja tygodnika, który pojawił się na rynku wydawniczym w połowie lat osiemdziesiątych XIX w., postawiła sobie za cel popieranie dążeń kobiet do równouprawnienia. Wzywano kobiety, aby zbudziły się i dążyły do zmiany swego stanowiska w rodzinie i społeczeństwie:

Nim słońce wzejdzie, wiele ona dróg ciężkich przebyć musi, wiele obmyśleć, zmienić, opatrzyć, wiele nauczyć się i zrozumieć. W chacie naszej ciemno, zimno i ubogo. W chacie naszej duszno i powietrza brak. Lepiej może tym, co śpią i nie czują tego. Ale kobieta wstać musi. Ona się już budzi... ${ }^{120}$

Lansowano więc zupełnie inny niż w pozostałych czasopismach wizerunek niewiasty. Wzorem osobowym była kobieta-obywatelka, świadoma swoich obowiązków społecznych. Waleria Marrené w 1885 r. z zadowoleniem podkreślała:

Kobieta-kwiat, kobieta-dziecię, kobieta-anioł stała się istotą, zdolną i ochotną podzielić z mężczyzną trudy życia, walki społeczne; nie cofa się przed zgłębieniem zawiłych problemów, ani przed konsekwencją własnych czynów. Taka tylko kobieta wśród trudnych obecnych warunków może podołać trudnościom bytu, jeśli wypadła jej samotna dola, lub stać się prawdziwą towarzyszką męża; taka tylko zdolną będzie wspierać go $w$ dniach złych, być mu osłodą w nieszczęściu, dźwignią w upadku, powiernicą w pomyślności, [...] taka tylko jest myślącą różą ${ }^{121}$.

Wskazywała, że niegdyś istniał stereotyp „kobiety biernej, cierpliwej, łagodnej, pięknej nade wszystko, pięknej koniecznie, umiejącej w nieszczęściu tylko wzdychać, płakać i umierać". Dziś społeczeństwo i rodzina wymagają od kobiety dużo więcej, „literatura więc, kierując się pożądaniami ogółu, zaczęła według nich typy swoje kształtować"122. Dlatego też radzono czytelniczkom:

118 Moje zwierciadło. Panna dobrze wychowana, KR 1912, nr 24, s. 375.

119 Posag dla panienek pragnących wyjść za mąż, KR 1913, nr 2, s. 31.

120 Słowo wstępne, Ś 1884, nr 1, s. 1.

121 W. M a r r e n é, Kobieta w powieści naszej, Ś 1885, nr 91, s. 198.

122 Tamże, nr 86, s. 153. 
Niechaj każda kobieta w domu swoim będzie promieniem słonecznym, który ogrzewa; niech miłośnie ma się ku wszystkiemu, co pod jej ręką i tchnieniem ma się ożywiać, rozrastać i rozwijać - a dom jej, jej otoczenie bogate czy biedne, odbije na sobie harmonijne, dopełniające się wzajem barwy jej duchowej istoty, ten ład moralny, z którego dopiero wypłynąć może pojęcie i zaprowadzenie zewnętrznego ładu ${ }^{123}$.

Zadaniem kobiet jest „być nauczycielkami dobra, piękna i prawdy, rozbudzać śpiące dusze, rozjaśniać zmroki, co je ogarnęły od wieków, prowadzić je ku jaśniejszym krańcom"124. Powinny być odpowiednio wykształcone, aby sprostać stojącym przed nimi zadaniom - żony („żona wykształconego człowieka musi posiadać wykształcenie, ażeby zrozumieć dążności i przekonania swego męża”"125) i matki ${ }^{126}$. Przekonywano, że „największym wrogiem dzisiejszej instytucji rodziny jest właśnie umysłowa niższość kobiet i społeczne ich stanowisko. One to bowiem stwarzają ową przepaść pomiędzy wykształconym mężczyzną-mężem i ciemną jego towarzyszką [...] one w końcu osłabiają w synach poczucie szacunku dla ciemnej ich rodzicielki i dla sióstr, nie rozumiejących się na tym, co ich obchodzić może i porywać” ${ }^{27}$. Podkreślano również, że wykształcenie kobiet „nie może być dodatkiem do reformy emancypacyjnej”, gdyż „ta od niego rozpocząć się winna i przez nie tylko znajdzie kiedyś właściwe i naturalne rozwiązanie”"128. Jedynie Adolf Dygasiński przekonywał o niższości umysłowej kobiety: „ona nie wytworzy nic samodzielnie, ale nauczy się gorliwie i skwapliwie wszystkiego, co jej podane zostanie”, a „kobietę na wyższe szczebel obowiązków i cnót moralnych, jako też na szerszą arenę życia obywatelskiego, poprowadzić może jedynie mężczyzna"129. W związku z tym próbował sprowadzić jej rolę w rodzinie głównie do wychowywania dzieci i dbania o męża. Dziwnie brzmiały jego słowa o „umysłowej niedoli” płci pięknej w piśmie, które postawiło sobie za cel walkę o równouprawnienie niewiast i zdobycie im wszelkich możliwych pól pracy zarobkowej.

Inni publicyści twierdzili, że pozycja społeczna kobiety powinna być taka, aby umożliwiło jej to sięganie po wykształcenie i zatrudnienia, zgodne z jej możliwościami i potrzebami, przy czym kwestia kobieca powinna być podporządkowana interesom ogółu. Apelowano o wyzyskanie kobiety dla społecznego dobra ${ }^{130}$. Chociaż odcinano się od postulatów emancypantek angielskich, walczących o prawa polityczne, to podkreślano, że istotna jest ich przewodnia zasada „prowadząca kobiety do pracy na wszystkich tych polach, gdzie mogą być narodowi

123 Silva rerum, Ś 1884, nr 1 (dodatek), s. 9.

124 J. K u d e I s k a, Z listów do „Świtu”, Ś 1885, nr 45, s. 40.

125 [I. L.], Średnie wykształcenie kobiet, Ś 1887, nr 153, s. 70.

126 Tamże.

127 J. K. P o t o c k i, Podległość kobiet (z powodu pracy J. S. Milla), Ś 1886, nr 138, s. 157.

128 J. G a d o m s k i, Przegląd literacki, Ś 1884, nr 13, s. 207.

129 A. D y g a s i ń s k i, Myśli o stanowisku kobiety ze względu na wychowanie społeczne, tamże, nr 23, s. 374 .

130 Kwestia kobieca, tamże, nr 2, s. 17. 
pożyteczne”131. Podkreślano, że „zdobywanie praw politycznych przez kobiety nas obchodzić może tylko pośrednio. Dla naszych kobiet ważniejszymi są prawa społeczne"132.

\section{Podsumowanie}

Chociaż wszystkie czasopisma przypisywały kobiecie szczególną rolę w życiu rodzinnym, to jednak na przestrzeni lat stosunek do tej kwestii redakcji i publicystów poszczególnych magazynów ulegał stopniowej ewolucji - od przyznania prawa do pracy wyłącznie w rodzinie i na jej użytek, aż do podejmowania działalności zawodowej i społecznej, traktowanych jako obowiązek wobec rodziny i wychowania przyszłych pokoleń. Takie stanowisko prezentowano w tygodnikach o umiarkowanym podejściu do równouprawnienia kobiet - w „Bluszczu” oraz „Tygodniku Mód i Powieści". Oba pisma w kwestii kobiecej opowiedziały się za wiernością tradycji, jednak w sprawach wykształcenia i pracy zawodowej przedstawiały program umiarkowany. Dostrzegając potrzeby społeczne i związaną z tym konieczność podejmowania przez kobiety pracy zarobkowej, wskazywały na potrzebę stworzenia dla nich nowych miejsc pracy, podsuwały pomysły, popierały dążenie dziewcząt do zdobycia fachowego przygotowania do obowiązków zawodowych. Zgadzało się to ze stanowiskiem i oczekiwaniami znacznej części czytelniczek, stąd czasopisma te przez tak długi czas cieszyły się niesłabnącą popularnością.

Najbardziej konserwatywny program proponowała swym czytelnikom „Kronika Rodzinna". Nawet wtedy, gdy po 1905 r. ruch kobiecy na ziemiach polskich rozwijał się coraz bardziej prężnie, miejsce kobiety widziano głównie w rodzinie, a jej obowiązki sprowadzano do bycia dobrą żoną i matką. Pomimo takiego podejścia także „Kronika Rodzinna” cieszyła się przez niemal pięćdziesiąt lat znaczną popularnością. Być może wynikało to $z$ faktu wskazywania na zgodność z wolą Bożą lansowanego modelu rodziny i odgrywanych w niej przez mężczyznę i kobietę ról. W społeczeństwie katolickim pismo mogło więc liczyć na wystarczającą liczbę prenumeratorów.

Najbardziej radykalny program w kwestii równouprawnienia prezentował „Świt”. Wprawdzie redakcja i publicyści nie domagali się dla kobiet praw politycznych, a jedynie akcentowali konieczność przewartościowania zagadnienia miejsca i roli niewiast w społeczeństwie, jednak - jak się okazało - społeczeństwo polskie lat osiemdziesiątych XIX w. nie było gotowe na przyjęcie takiego stanowiska. Obawiano się rozszerzenia na ziemiach polskich ruchu emancypacyjnego, widziano w nim zagrożenie dla życia rodzinnego i w związku z tym - przyszłości narodu. Uważano, że w czasach niewoli jedynie rodzina może zapewnić ciągłość

131 Walka o prawa polityczne, tamże, nr 10, s. 153.

132 J. K. P o t o c k i, Podległość kobiet..., nr 139, s. 164. 
przekazu tradycji i uznanego systemu wartości, a w tej rodzinie szczególne miejsce przypada kobiecie. Jeśli opuści ona rodzinę dla pracy zawodowej lub działalności społecznej, społeczeństwu niewątpliwie zagrozi zagłada. O bezpodstawności takich obaw przekonywali czytelniczki publicyści „Bluszczu” oraz „Tygodnika Mód i Powieści", jednak działo się to dopiero ponad dwadzieścia lat później, gdy zmieniające się warunki życia wymusiły na kobietach konieczność poszukania pracy zarobkowej poza rodziną. Redakcja „Świtu” zbyt wcześnie lasowała poglądy, które mogły zostać urzeczywistnione dopiero przez przedstawicielki następnego pokolenia Polek. Dlatego też, ze względu na szybko malejącą liczbę czytelniczek, pismo zostało zlikwidowane zaledwie po trzech latach istnienia. 